\title{
Canine rabies epidemiology in Araçatuba and neighborhood, Northwestern São Paulo State - Brazil
}

\author{
Epidemiologia da raiva canina na região de Araçatuba, Noroeste \\ do Estado de São Paulo - Brasil
}

\author{
Luzia Helena Queiroz da Silva ${ }^{1}$, César Eduardo Bissoto ${ }^{1}$, Ádna Cleia B. Delbem ${ }^{1}$, \\ Clara Isabel de Lucca Ferrari ${ }^{2}$, Sílvia Helena Venturoli Perri ${ }^{1}$ and Cáris Maroni Nunes ${ }^{1}$
}

\begin{abstract}
Epidemiological characteristics of canine rabies in the northwest region of São Paulo State (Araçatuba region), Brazil, from 1993 to 1997 are presented. Out of 1,984 dogs, a total of 351 (17.7\%) were positive for rabies diagnosis; 89\% (312/ 351) of these occurred in urban areas and 85\% ( 266/312) of the urban positive cases were among owned dogs. The mean age of the rabid dogs was 34 months and $61 \%$ were male. Aggressive behavior was observed in $77 \%$ of rabid dogs, followed by lack of coordination and paralysis ( $42 \%$ ) and $48 \%$ of these dogs were responsible biting people or other animals. Information about vaccination status was obtained from 182 records and $51 \%$ of rabid dogs were non-vaccinated. The number of unvaccinated rabid dogs indicates a low vaccination index and this factor added to the high dog/man ratio must have contributed to the canine rabies epizootic observed in the studied area.
\end{abstract}

Key-words: Dogs. Canine rabies. Epidemiology. São Paulo State.

\section{RESUM0}

São apresentadas algumas características epidemiológicas da raiva canina na região de Araçatuba, no período de 1993 a 1997. Dentre 1.984 cães submetidos ao diagnóstico de raiva, 351 foram positivos sendo que 89\% dos casos (312/351) ocorreram na zona urbana e destes, 85\% (266/312) eram de animais com proprietário. As informações sobre sexo estavam presentes em $83 \%$ das fichas e destas $61 \%$ eram de machos. A média de idade dos cães positivos foi de 34 meses. A agressividade foi um dos sintomas mais comumente observado (77\%), seguido por incoordenação motora e/ou paralisia (42\%) e 48\% dos cães positivos haviam agredido pessoas ou outros animais. Das 182 fichas epidemiológicas que possuíam dados de vacinação, 51\% (92/182) dos cães não eram vacinados. Aponta-se como possíveis razões para 0 aparecimento da epidemia no município de Araçatuba a baixa cobertura vacinal demonstrada pelo índice de cães não vacinados que adquiriram a doença aliado à elevada relação cão/homem $(1: 3,5)$ revelada em estudo anterior.

Palavras-chaves: Cães. Raiva canina. Epidemiologia. Estado de São Paulo.

Canine rabies continues to be a major public health problem in most parts of the world. Human rabies transmitted by rabid dogs corresponds to $76.6 \%$ of the recorded cases in the Americas $^{7}$ and to $83 \%$ of registered cases in São Paulo State, Brazil, from 1980 to $1994^{12}$. Considering that the estimated dog population in Latin America and the Caribbean is about 40 million, which corresponds to one dog for every 8-13 inhabitants ${ }^{1}$, dogs play an important role in rabies occurrence.

During the period from 1970 to 1980, Brazil registered an annual average of 2,400 cases of canine rabies ${ }^{6}$. Rabies control measures such as mass dog vaccination campaigns have been undertaken, resulting in a considerable reduction in the number of human and dog rabies cases ( $78 \%$ and $90 \%$ decrease in human and dog rabies cases, respectively) during the period of 1980 to 1990 . However, at the end of the decade the incidence has increased again ${ }^{8}$. From 1990 to 1999, Brazil registered an average of 870.3 cases of rabies in $\operatorname{dogs}^{10}$.

In the northwestern region of São Paulo State an epidemic of canine rabies initiated in 1991 and disseminated to the neighboring districts at a rate of $26.4 \mathrm{~km}$ per year, reaching 10

1. Curso de Medicina Veterinária do Departamento de Apoio, Produção e Saude Animal da Universidade Estadual de São Paulo, Araçatuba,SP. 2. Laboratório de Sanidade Animal e Vegetal do Instituto Biológico, Araçatuba, SP, Brasil.

Address to: Dra. Luzia Helena Queiroz da Silva. R. Clóvis Pestana 793, 16050-680 Araçatuba, SP, Brasil.

Tel: 5518 3620-3298, Fax: 5518 3622-6487.

E-mail: lhqsilva@fmva.unesp.br

Recebido para publicação em 01/04/2003

Aceito em 22/12/2003 
municipal districts. Dogs represented $87.2 \%$ of the total positive animal samples ${ }^{10}$. As a consequence of this canine epidemic, two human rabies cases were registered in Araçatuba and Avanhandava, in 1994 and 1997, respectively (Instituto Pasteur/ São Paulo, unpublished data) .

In spite of the fact that canine rabies epidemics have been reported all over the world, epidemiological descriptions are scarce ${ }^{3}$, especially in Brazil. This work presents some epidemiological characteristics of the canine rabies epidemic in the northwestern region of São Paulo State, Brazil, from 1993 to 1997.

\section{MATERIAL AND METHODS}

The studied area comprises 42 municipal districts that sent at least one canine sample for examination during the study period. Positive cases were analyzed from nine municipal districts of varying size, in the northwestern São Paulo State, where a canine rabies epidemic has been observed ( Figure 1).

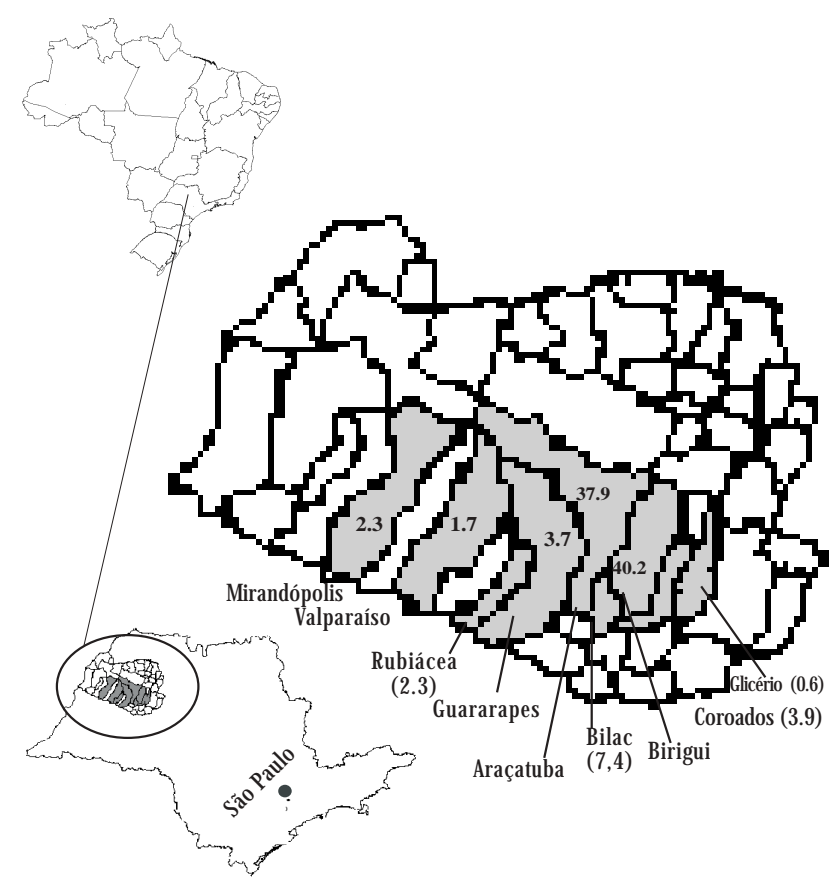

Figure 1 - Map of Brazil showing São Paulo State and Araçatuba region (in detail), with the percentage of positive dogs in each district related to the total number of positive samples in the whole Araçatuba region.

Rabies diagnosis was performed by fluorescent antibody and mice inoculation tests, according to the World Health Organization recommendations ${ }^{13}$.

Using a data base program (Dbase 3 Plus ${ }^{\circledR}$ ) , epidemiological files from 351 dogs with positive rabies laboratory diagnosis were evaluated in that region, from 1993 to 1997. Data on the origin, environment, breed, age, sex, rabies vaccination status, clinical signs, aggression and ownership conditions were analyzed. Unfortunately, not all the files contained complete information concerning the analyzed data and in most of the cases it was not possible to obtain further details.

The chi-square test was used for specified proportions ${ }^{14}$.

\section{RESULTS}

Table 1 shows the number and percentage of examined samples and rabies positive dogs during the studied period according to their origin. A total of 1,984 samples were evaluated and 351 (17.7\%) were positive by either fluorescentantibody test or mice inoculation test. The highest percentage of positivity ( number of positive samples from the examined samples) was observed in Rubiacea district, where almost all the examined samples tested positive (88.9\%). Figure 1 shows these cases according to their geographical distribution and the percentage in each district. The highestnumbers of positive cases, from the total detected cases, were observed in the municipal districts of Birigü ( 40.2\%) and Araçatuba ( 37.9\%).

Table 1 - Number and percentage of examined dogs and rabies positive diagnosis, according to the origin of municipal district in Araçatuba region from 1993 to 1997.

\begin{tabular}{lccc}
\hline District & $\begin{array}{c}\text { Number of } \\
\text { examined samples }\end{array}$ & $\begin{array}{c}\text { Number of } \\
\text { positive samples }\end{array}$ & Positivity \% \\
\hline Araçatuba & 623 & 133 & 21.3 \\
Birigui & 718 & 141 & 19.6 \\
Bilac & 52 & 26 & 46.4 \\
Coroados & 62 & 14 & 22.5 \\
Glicério & 27 & 02 & 7.4 \\
Guararapes & 49 & 13 & 26.5 \\
Mirandópolis & 61 & 08 & 13.1 \\
Rubiácea & 09 & 08 & 88.9 \\
Valparaíso & 25 & 06 & 24 \\
Others & 358 & 0 & 0 \\
Total & 1984 & 351 & 17.7 \\
\hline
\end{tabular}

Figure 2 presents the distribution of all recorded positive cases according to the quarters of the year. There was a significant increase $(p<0.001)$ in the frequency of cases during the first and second quarters of 1994.

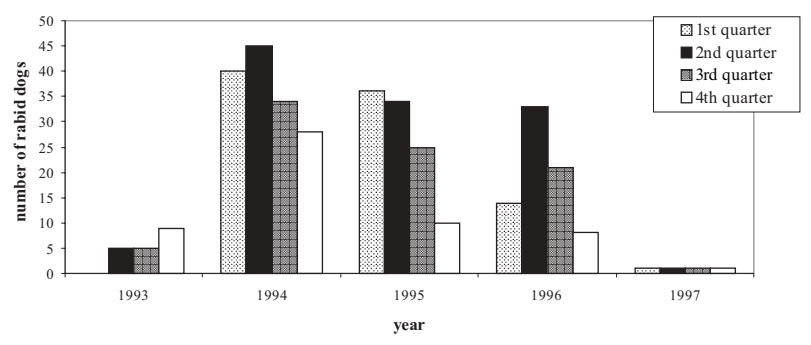

Figure 2 - Distribution of positive cases according to quarters of year, from 1993 to 1997.

The highest proportion of dogs, corresponding to $89 \%$ (311/351) originated from urban areas, whereas only $11 \%$ (39/351) were from rural areas. Among the urban positive cases 85\% (266/311) were owned dogs.

A total of 324 files had information about the breed of the animals and 280 corresponded to mongrel dogs ( 86\%). Eighty three percent (292/351) of the files had information aboutsex and $61.0 \%$ corresponded to males and $39.0 \%$ to females $(p<0.001)$. 
Table 2 shows information regarding age, which was obtained from 208 files ( $59 \%$ of the total). The median age of the rabid dogs was 34 months and the highest age frequency was 24 to 48 months corresponding to $26 \%(\mathrm{p}<0.001), 12$ to 24 months and 6 to 12 months, both with $17.3 \%$ occurrence.

Table 2 - Number and percentage of dogs with positive rabies diagnosis, according to their age in Araçatuba region from 1993 to 1997.

\begin{tabular}{lcr}
\hline Age (months) & Number & $\%$ \\
\hline$<3$ & 10 & 4.8 \\
$3-6$ & 25 & 12.0 \\
$6-12$ & 36 & 17.3 \\
$12-24$ & 36 & 17.3 \\
$24-48$ & 54 & 26.0 \\
$48-72$ & 20 & 9.6 \\
$72-96$ & 11 & 5.3 \\
$96-120$ & 10 & 4.8 \\
$>120$ & 6 & 2.9 \\
Total & 208 & 100.0
\end{tabular}

Concerning clinical findings, $23 \%$ of the files did not contain any information. From a total of 269 animals for which atleastone sign was reported, aggressiveness was the most frequent sign (77\%) followed by lameness and limb paralysis (42\%), change in voice (30\%) and jaw paralysis with excessive salivation (26\%). Lethargy was reported in only $11 \%$ of the dogs. Most of the files (97\%), contained information about aggression and in 48\% (162/340) of the cases, rabid dogs had bitten a human or other animal. Ninety one percent (148/162) of these aggressors were owned dogs.

During the analyzed period, dogs were responsible for the transmission of rabies to 21 herbivores including 12 cattle, 6 horses, 2 pigs and 1 sheep, 19\% of which (4/21) corresponded to animals kept in urban areas.

Vaccination status was informed in 52\% (182/351) of the files and 51\% (92/182) of these dogs, had never been vaccinated against rabies.

Figure 3 presents the distribution of rabid dogs according to age and vaccination status. The highest percentage of rabid vaccinated dogs was $50.0 \%$ and occurred between the age of 12 and 24 months as well as in dogs over ten years old.

From a total of 182 registers that had information about vaccination status, 54 rabid dogs (29.6\%) were owned, aggressive and unvaccinated against rabies.

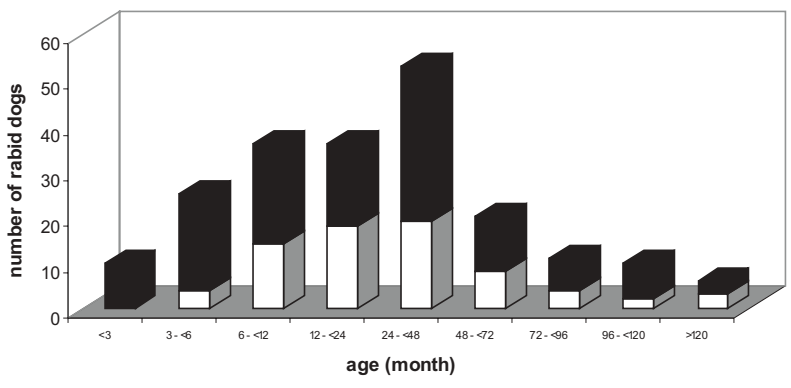

$\square$ vaccinated $\boldsymbol{\square}$ total

Figure 3 - Number of rabid dogs, according to the age and vaccination status, when recorded.

\section{DISCUSSION}

In the lastfewyears urban rabies control in Brazil and specifically in the northwestern São Paulo State region was undertaken mostly by mass immunization campaigns besides laboratory diagnosis of suspected rabid animals. In the five years prior to the rabies epidemic, vaccination coverage in Araçatuba region had reached $80.0 \%$ of the total estimated dog population (approximately 15,000 dogs), considering a dog-to-person ratio 1: 8-13', which is usually used as a basis in many American countries. However, the dog-to-person ratio observed in this region was 1:3.5 indicating that possibly, the real coverage was below this estimation 5 . Consequently, urban rabies outbreaks appeared in many municipal districts of the region, particularlyin Araçatuba contributing to the epidemic progression towards the East, reaching a total distance of $152 \mathrm{~km}^{10}$.

The increase in the number of cases observed during the first and second quarters of 1994 occurred just after the first human rabies case registered in January 1994 in Araçatuba. This might have contributed to the increased number of samples sent for rabies diagnosis. In addition, the large number of free roaming dogs and the poor capture service allowed a rapid dissemination of rabies virus among the dog population.

In the urban areas of these districts, where the highest concentration of dogs is recorded, our results show that most of the rabid dogs were owned. However, they were certainly not restrained when outdoors, which is a common custom in developing countries ${ }^{2}$.

The highest percentage of positive male dogs (61\%) might be due to the fact that when free roaming females are in heat, fights will be more numerous and the roaming range will expand and also because they usually define their territory and challenge any dog which does notbelong to their group ${ }^{1}$. Similar results were described in Mexico ${ }^{3}$ and the United States ${ }^{2}$ where authors described the highest percentage of positive rabies cases occurring in males.

Concerning the age distribution of positive dogs, the highest frequencies were observed between 6 and 48 months, which corresponds to $60.6 \%$ of the cases, probablybecause of the lack of vaccination or immune response. Eng et al ${ }^{3}$ observed that the highest frequency of rabid dogs in Mexico was between 6 and 12 month of age when they had a great mass of unvaccinated dogs. In the present study, aggressiveness was observed in $77 \%$ of the cases that had information on clinical signs while the same symptom was observed in 29.3\% of rabid dogs in United States². The high percentage of dogs showing aggressiveness in our study, is related to the high frequency (47.6\%) of dogs thathad bitten humans or other animals. It should be emphasized that $61.7 \%$ of the aggressors were owned, and only $46 \%$ were vaccinated againstrabies. These observations reflect the carelessness of the owners, mainly concerning vaccination and allowing their pets to roam freely on the streets.

Reports of rabies in vaccinated dogs especially among younger animals that have a higher susceptibility to infection and probably do not have an adequate seroconversion and protection $^{3}$ is quite common but, in our study, this proportion corresponded to $49 \%$, which means that almost half of the 
rabid dogs had been vaccinated at least once. Rabies vaccine used for Brazilian dog vaccination campaigns is an inactivated suckling mouse brain vaccine, tested for potency by Ministry of Agriculture, using Habel test ${ }^{4}$ with a minimum titer of $10^{6.0}$ LD $50 / 0.03 \mathrm{ml}$ ( $50 \%$ Lethal Doses). Among the vaccinated dogs, the highest percentage of rabies occurred in those aged between 12 and 24 months ( 50\%) emphasizing the observations already made in an earlier study that only after receiving three or more doses of vaccines in mass campaigns, over consecutive years, the animals will present adequate and durable rabies antibodies levels ${ }^{11}$. Similar results showing the benefits of several vaccinations on the antibody titers were reported by Seghaier et $\mathrm{al}^{9}$. To better discuss these data, more information is necessary about the time between the last vaccination and death, the age of first vaccination and the number of doses received during their lifetime, unfortunately however, such information is not available in local records.

Our findings show the necessity of intensifying control measures, population health education, specially referring to responsible ownership, which involves adequate vaccination and restricting pets from street roaming, in addition to daily care.

We consider that this kind of report is important for epidemiological surveys and can help to modify rabies control measures and contribute to a better understanding of the dynamics of urban dog populations.

\section{ACKNOWLEDGEMENTS}

To UNESP Veterinary Hospital Pathology Service for necropsy of dogs. To Cristiano de Carvalho for the preparation of the samples and Devani Mariano Pinheiro for care of the laboratory mice. To Dr. Florance Cliquet from AFSSA-Nancy ( France) for the various suggestions regarding this manuscript.

\section{REFERENCES}

1. Chomel BB. The modern epidemiological aspects of rabies in the world. Comparative Immunology Microbiology and Infectious Disease 16:11-20, 1993.

2. Eng TR, Fishbein DB. Epidemiologic factors, clinical findings and vaccination status of rabies in cats and dogs in the United States in 1988. Journal of American Veterinary Medical Association 197:201-209, 1990.

3. Eng TR, Fishbein HE, Talamante HE, Hall DB, Chavez GF, Dobbins JG, Muro FJ, Bustos JL, Ricardy MA, Munguia A, Carrasco J, Robles AR, Baer GM. Urban epizootic of rabies in Mexico: Epidemiology and impact of animal bite injuries. Bulletin of World Health Organization 71: 615-624, 1993.

4. Habel K. Pruebas de inocuidad y potencia de las vacunas. In: Kaplan MM, Koprowsky H (eds) La rabia. Tecnicas de laboratorio, $3^{\text {rd }}$ edition, Organizacion Mundial de la Salud ( Serie Monografias n.23), Ginebra, p. 311, 1976.

5. Nunes CM, Martines DA, Fikaris S, Queiroz LH Avaliação da população canina da zona urbana do município de Araçatuba, São Paulo, Brasil. Revista de Saúde Pública 31:308-309, 1997.

6. Organizacion Panamericana de la Salud. Vigilância Epidemiologica de la Rabia en las Américas. Vol XXIII 1993.

7. Organizacion Panamericana de la Salud. Boletin de Vigilância Epidemiologica de la Rabia en las Américas. Vol XXXI; 1999.

8. Schneider MC, Almeida GA, Souza LM, Morares NB, Diaz RC. Controle da raiva no Brasil de 1980 a 1990. Revista de Saúde Pública 30:196-203, 1996.

9. Seghaier C, Cliquet F, Hammami S, Aouina T, Tlatli A, Aubert M. Rabies mass vaccination campaigns in Tunisia: are vaccinated dogs correctly immunized? American Journal of Tropical Medicine and Hygiene 61:879-84, 1999.

10. Silva LHQ, Ferrari CIL, Peixoto ZMP, Cunha EMS, Gonsales CM . Diagnóstico laboratorial da raiva na região de Araçatuba no período de Janeiro/1993 a Dezembro/1995. 0 Biológico, São Paulo 58:7-12, 1996.

11. Silva LHQ, Nunes CM, Sant'anna OA Humoral response to Fuenzalida vaccine in Brazilian dogs. In: Abstracts of the IX International Meeting on Research Advances and Rabies Control in the Americas, Puerto Vallarta - México p.68-69, 1998.

12. Takaoka NY. Considerações sobre a raiva humana transmitida por quirópteros no Estado de São Paulo. Boletim do Instituto Pasteur, São Paulo 1:59-61, 1996.

13. World Health Organization. Laboratory Techniques In Rabies. $4^{\text {th }}$ edicion Geneva, 1996.

14. Zar JH. Biostatistical Analysis. New Jersey: Prentice-Hall, $4^{\text {th }}$ edicion 1992. 